\title{
Lupin as a perspective protein plant for animal and human nutrition - a review
}

\author{
Kateřina Sedláková, Eva Straková, Pavel Suchý, Jana Krejcarová, Ivan Herzig \\ University of Veterinary and Pharmaceutical Sciences Brno, Faculty of Veterinary Hygiene, \\ Department of Animal Nutrition, Brno, Czech Republic \\ Received December 13, 2015 \\ Accepted May 2, 2016
}

\begin{abstract}
The development of new varieties of lupin, so-called "sweet lupins" with low alkaloid (bitter substances) and high protein content has resulted in a renewed interest in utilization of lupin as source of proteins in human and animal nutrition. The nutraceutical potential of lupin can be applied in the prevention from various pathological states in humans; by suppressing appetite and affecting energy balance, by its positive effect on glycaemia and indicators of blood lipids, by its positive influence on hypertension and by improving defecation. In the field of animal nutrition, lupin seeds can positively affect both production indicators and the biological value of food of animal origin.
\end{abstract}

Nutrients, anti-nutritional substances, legumes, nutraceutical potential

The Lupinus genus includes approximately 300 species of annual and perennial herbs. A number of them had been grown and had been part of human diet, as well as feed for animals in the Mediterranean region for centuries. At the beginning of the last century, new, so-called "sweet" lupin varieties low in alkaloids (bitter substances) and high in proteins were developed. That was an impulse for renewed interest in its utilization and lupin became the source of proteins in the nutrition of both humans and animals (Dijkstra et al. 2003). So in the $20^{\text {th }}$ century, lupin became part of modern agriculture and food systems.

In Europe, mainly two varieties are grown: Lupinus luteus and L. albus, while in Australia it is L. angustifolius (Cowling et al. 1998). The development of varieties with solid pods and varieties low in alkaloids allowed that these varieties stopped being used as green manure and soiling crops and became legumes grown for seeds.

The nutrient composition of lupin seeds is exceptional, it has a high content of proteins and soluble fibre and, unlike cereals, a low content of starch (Petterson et al. 1997). Lupinus albus, L. angustifolius, and L. luteus have a relatively low content of oil - 10, 6, and $5 \%$, respectively, while for example L. mutabilis has approximately $18 \%$ of oil and with its composition, it approaches soy. Lupins do not contain anti-nutritional factors such as trypsin inhibitors and saponins. As the source of energy they compete with cereals and as the source of proteins with oil seed meals. The lupin value is enhanced by the capacity to supplement other food components to achieve an overall balance of nutrients. Lupin has recently expanded as a food supplement, mainly in Europe.

The largest world producer and exporter of lupin seeds is Australia with $80-85 \%$ of the world's production, of which $90-95 \%$ are exported all over the world including Europe. The biggest silos in Australia where lupin seeds are stored and from where they are distributed to all over the world are located in Western Australia. The most significant lupin growing regions in Europe are in Germany, France, Benelux, Spain, Poland, Ukraine, and Russia. In the Czech Republic, lupin is grown on an area of approximately 7,000 ha. 


\section{Significant nutrient and dietetic components}

In the dry matter of seeds of lupin varieties approved in the Czech Republic (Lupinus albus, L. angustifolius, L. luteus) individual constituents are in a relatively wide range, depending on the variety and climatic conditions (Straková et al. 2006): $(\mathrm{g} / \mathrm{kg}$ ) proteins 317.1-458.9, fats 52.2-125.8, fibre 101.2-154.2, nitrogen-free extract 285.9-436.5, starch 41.3-102.6, organic matter 951.8-966.2, ash 33.8-48.2, calcium 2.3-5.1, phosphorus 4.6-8.0, magnesium 1.4-2.5, and acid-detergent fibre 133.1-209.3.

\section{Proteins and amino acids}

The above mentioned implies a large difference in the chemical composition of individual seed varieties of the Lupinus genus. However, it is important that lupin seeds are characteristic for its high content of proteins, in yellow varieties it largely exceeds the protein content in soybeans. Compared to soy protein, the amino acid composition is characterized with a low content of methionine, cysteine, lysine, threonine, and tryptophane, while the arginine content is significantly higher (Suchý et al. 2006a,b; Stanek et al. 2006). High arginine content is characteristic for lupin protein.

\section{Polysaccharides}

The main component of polysaccharides is non-starch polysaccharides which are excellent sources of food fibre with a high water binding capacity. Compared to other legumes, lupin seeds contain more dietetically beneficial crude fibre. The proportions of insoluble and soluble fibres are $21.5 \%$ and $2.2 \%$, respectively, in the dehulled lupin seed, and $86.2 \%$ and $1 \%$, respectively, in the hull (Johnson and Gray 1993). Lupin fibre has the capacity to decrease cholesterol level, to improve peristalsis and to reduce the time of passage of the intestinal content through the digestive apparatus. In the seeds of lupin varieties grown in Europe, the content of crude fibre is from 94.4 to $142.0 \mathrm{~g} / \mathrm{kg}$, aciddetergent fibre from 124.2 to $192.2 \mathrm{~g} / \mathrm{kg}$ and it is higher compared to soybean (Straková et al. 2006).

\section{Fats and fatty acids}

Compared to soybeans, lupin seeds grown in Europe have a significantly lower content of fat, ranging from 52.2 to $125.8 \mathrm{~g} / \mathrm{kg}$ (Straková et al. 2006) in the original matter of the monitored varieties. As regards white lupin of Amiga variety, the authors (Zralý et al. 2008; Písaříková and Zralý 2009) found out a fat content of $107.7 \mathrm{~g} / \mathrm{kg}$. In Butan variety, the content in a whole or dehulled seed is 79.1 and $102.3 \mathrm{~g} / \mathrm{kg}$ of dry matter. Lupin seed oil is a rich source of unsaturated fatty acids such as oleic and linoleic acids (up to $80 \%$ ) (Yanez et al. 1983). From the nutritional point of view, lupin oil has a very favourable ratio of $\omega-3$ to $\omega-6$ fatty acids. On the basis of our own analyses within the individual varieties registered in the Czech Republic, it ranges from 1:1.7 to 10.8.

\section{Macro-elements, micro-elements, and vitamins}

The calcium content in original matter in lupins grown in Europe ranges from 2.1 to 4.7, the phosphorus content from 4.3 to 7.2 , the magnesium content from 1.2 to $2.2 \mathrm{~g} / \mathrm{kg}$, the potassium content from 8.6 to 11.1 , and the sodium content from 0.1 to $0.2 \mathrm{~g} / \mathrm{kg}$ (Zeman et al. 1995). A high manganese content $(896 \mathrm{mg} / \mathrm{kg})$ was detected in L. albus.

Fortification of lupin in ferritin may be a way to obtain a good source of iron in the diet. Lupin seeds compared to other plants, have an enormous tolerance to the presence of iron in their growing environment. The experiments conducted confirmed the stability of obtained plant ferritin in some food products, such as pastas and extruded and bakery products (Zielinska-Dawidziak 2015). 
Lupins contain an average amount of carotenoids: $\beta$-carotene, lutein and zeaxanthin, tocopherols and other bioactive components with a stimulating potential. An interesting component of the lipidic fraction of lupin is lupeol, triterpene alcohol having an effect on improving the renewal of epidermal tissue (Msika et al. 2006). Using a microbial biosynthesis, it is possible to increase the content of vitamin B12 in lupin meal (ChandraHioe and Arcot 2015).

\section{Anti-nutritional substances}

Compared to bitter varieties, the proportion of anti-nutritional substances (quinolizidine alkaloids) in the newly developed sweet varieties of lupin decreased substantially and they are only present there in trace amounts. Therefore the seeds of sweet varieties and the products made out of them can be considered suitable for human consumption and also for feeding ruminants and mono-gastric animals (Aniszewski et al. 2001).

The effect of ensiling moist field bean (Vicia faba), pea (Pisum sativum) and lupin (Lupinus spp.) grains on the contents of alkaloids, oligosaccharides and tannins was studied by Gefrom et al. (2013). As an overall effect, lactic acid fermentation reduced the content of tannins and oligosaccharides. As mentioned by Green et al. (2012), hemlock (Conium maculatum), lupin (Lupinus spp.) and tabacco (Nicotiana tabacum) contain teratogenic piperidine alkaloids. Piperidine alkaloids are acutely toxic to adult livestock species and produce musculoskeletal deformities in neonatal animals. These teratogenic effects include multiple congenital deformities in cattle, pigs, sheep, and goats.

Alkaloids present in blue lupin (Lupinus angustifolius) given to rats at several concentrations $(0.36,0.41,0.56 \mathrm{mg} / \mathrm{kg})$ for a period of 28 days reduced the feed intake and significantly reduced the growth of experimental rats compared to the control group. The final weight of the control was 188.6, while those of the experimental groups were 135.2, 134.1, and $130.4 \mathrm{~g}$ (Stanek et al. 2015).

\section{Utilization of lupin in human nutrition}

\section{Nutraceutical potential of lupin}

Foods enriched with lupin have a nutraceutical potential ("nutraceutical" is a term created by combining the word "nutrition" and "pharmaceutical"), i.e. they have a positive effect on health and prevention (treatment of diseases):

- causing feeling of satiety (appetite suppression) and affecting the energy balance,

- favourably affecting glycaemia,

- improving the levels of blood lipids,

- having a positive effect on hypertension,

- improving defecation.

Pharmaceutical and nutraceutical companies regard some lupin components as strategic molecules for prevention and possibly even therapy of various pathological states including the metabolic syndrome (a collective name for a simultaneous occurrence of abdominal obesity, increased triglyceride level, decreased HDL cholesterol concentration, hypertension, and hyperglycaemia (fasting), which is typical of rich countries and is included in the so-called civilization diseases (Duranti 2006).

The limited number of studies reporting the effect of lupin foods on metabolic syndrome risk factors have revealed some potentially health-protective effects. Further evidence from long-term human studies in those with metabolic syndrome such as the obese, insulinresistant/type 2 diabetic, hypercholesterolaemic and hypertensive is now required to substantiate the metabolic benefits of lupin consumption (Hodgson et al. 2015).

Influence of diets supplemented with soy, flaxseed and lupin products treated by 
lactofermentation on improving the gut health of Wistar rats was studied by Bartkiene et al. (2013). This study proposes the contribution of lactic acid bacteria and plants rich in bioactive substances and high-quality proteins as alternative products for human diets in improving the gut environment as potential protection against pathogenic bacteria. The effect of diets supplemented with soy, flaxseed and lupin flours fermented with the Pediococcus acidilactici KTU05-7 probiotic strain in the gastrointestinal tract (GIT) of Wistar rats was analyzed. In vivo experiments showed a positive effect of long-term lactofermentation of plant material on the body weight of rats. Diets with fermented yellow lupin resulted in enhanced activities of $\alpha$-glucosidase and $\beta$-galactosidases. High contents of lactic acid bacteria, bifidobacteria and enterococci in the GIT were also determined. Lactofermentation of analyzed plant products had a significantly lowering effect on Escherichia coli compared to the control group. The dominant flora of large intestines such as Bifidobacterium and anaerobic cocci were found in high levels after diets with fermented lupin.

Bouchenak and Lamri-Senhadji (2013) state that legumes (lupins, green beans and peas, peanuts, soybeans, and others) represent an important component of the human diet in several areas of the world, especially in the developing countries, where they compensate for the lack of proteins from cereals, roots, and tubers. The physiological effects of different legumes vary significantly. These differences may result from the polysaccharide composition, in particular the quantity and variety of dietary fibres and starch, protein, and variability in the phytochemical content. The majority of legumes contain phytochemicals: bioactive compounds, including enzyme inhibitors, phytohaemagglutinins (lectins), phytoestrogens, oligosaccharides, saponins, and phenolic compounds, which play metabolic roles in humans who frequently consume these foods. Dietary intake of phytochemicals may provide health benefits, protecting against numerous diseases or disorders, such as the coronary heart disease, diabetes, high blood pressure and inflammation. The synergistic or antagonistic effects of these phytochemical mixtures from food legumes, their interaction with other components of the diet, and the mechanism of their action have remained a challenge with regard to understanding the role of phytochemicals in health and diseases.

\section{Short-time effect on satiety (appetite suppression) and on the energy intake}

Bread enriched with lupin seed meal may decrease appetite for a short time and, compared to white bread, the plasmatic response of ghrelin changed considerably, which was in accordance with the observed short-time effect on satiety and energy intake (Lee et al. 2006). Incorporation of lupin seed fibre in processed foods resulted in the feeling of satiety for a period of up to $4.5 \mathrm{~h}$ after eating and in approximately $15 \%$ lower energy intake during the tested day (Archer et al. 2004). There is evidence that a diet with a high content of proteins compared to a diet with a high content of sugars, or a diet with a high content of fibre compared to a diet with a low content of fibre, fills more and has an effect on decreasing the food intake.

\section{Cardiovascular disease prevention}

The grown varieties of "sweet" lupins have very low allergenicity and a positive effect on prevention of cardiovascular diseases, which contributes to the development of their food utilization. The consumption of lupin proteins beneficial to health was examined in animal models and in clinical studies. Compared to control animals, the proteins of white and narrow-leaved lupin administered to rats resulted in significantly lower levels of both plasmatic cholesterol and triglycerides. In rabbits with atherosclerosis, compared to the control group fed with casein, the proteins of white lupin reduced the occurrence of atherosclerotic lesions. Whole lupin seeds administered to chickens (Viveros et al. 2007) and pigs (Martins et al. 2005) proved reduction in cholesterol. Apart from that, 
the isolates of lupin proteins and fibre may also reduce lipids in serum. In rats, the protein lupin isolates substantially decreased the total cholesterol concentration by $21 \%$ (Sirtori et al. 2004). In humans, adding 17 to $30 \mathrm{~g}$ of fibre of lupin fibre isolate per day reduced the concentrations of total and LDL cholesterol by approximately 5\% (Hall et al. 2005). The effect of lupin on decreasing cholesterol was proven also in a pilot clinical study which indicated a possible effect on blood pressure reduction.

By adding lupin protein isolates to the diet of different animal models of hypercholesterolaemia, such as the rat, rabbit, hamster and pig, significant decreases of total and non-HDL cholesterol were observed. These results are confirmed by clinical trials, with the limitation that only those involving hypercholesterolaemic subjects and based on improved lupin foods give significant total and/or LDL-cholesterol reductions (Arnoldi et al. 2015).

Kapravelou et al. (2013) also proved the favourable action of lupin protein hydrolyzate, combined or not with lupin insoluble fibre. The protein hydrolyzate was effective in reducing plasma and hepatic triglycerides and showed promising effects on glucose metabolism as well as protection against dietary-induced renal alterations.

Lammi et al. $(2014,2015)$ state that their findings indicate that peptides obtained from the hydrolysis of lupin proteins are able to interfere with the 3-hydroxy-3-methyl-glutarylCoA reductase activity. Immunoblotting experiments showed that the treatments with lupin peptides induce an up-regulation of the sterol regulatory element binding protein 2 (SREBP2) protein level and consequently to the up-regulation of the LDL receptor. From a functional point of view, the increase of LDL receptor proteins leads to an increase of the Hep G2 (a human liver carcinoma cell line) cells ability to up-take LDL with final hypocholesterolaemic effects.

Bouchenak and Lamri-Senhadji (2013) in their review provide an overview of the nutritional quality of legumes (including lupin) and their potential contribution in cardiometabolic risk prevention.

\section{Blood pressure}

An increase in the content of proteins at the expense of refined sugars in the diet may have a favourable influence on blood pressure. A study using the hypertension model in the rat sensitive to salt has shown that lupin proteins may mitigate the development of hypertension and improve endothelial functions (Pilvi et al. 2006). Lupin proteins have a relatively high content of arginine which is the precursor of the nitrogen oxide synthesis. A decrease in blood pressure may be caused by improving the vessel tonus caused by nitrogen oxide - a strong endothelial relaxation factor. However, it is difficult to speculate about mechanisms if several factors (proteins, sugars, fibre) are changed simultaneously in a diet.

Increased dietary fibre may have a favourable influence on a blood pressure decrease. Many of the experimentally verified studies monitored the effect of an increasing fibre intake on blood pressure. The meta-analyses of these experiments found that an increase in fibre intake by $>10 \mathrm{~g} /$ day was connected with a decrease of systolic and diastolic blood pressure by 1 to $1.5 \mathrm{~mm} \mathrm{Hg}$ (Streppel et al. 2005; Whelton et al. 2005).

\section{Luteins in lupin and central macula degeneration}

The studies performed show that lutein, which is found in the macula to large extent, probably filters short or blue light wavelengths. The studies performed in this field indicate that blue light causes oxidation stress and results in producing free radicals which damage the macula. People with a low carotenoid level in blood, mainly lutein and zeaxanthin, show a higher probability of the development of age-related macular degeneration (AMD). Protection in the form of lutein and zeaxanthin is probably connected with their capacity to filter shorter light wavelengths and with their anti-oxidation activity. Lupins are known 
as a rich source of lutein and this lutein can be a suitable diet component which delays the start and slows down the development of the consequences of AMD. Lutein does not cure AMD, but it can affect the progression of this disease (Fryirs et al. 2008).

\section{Bowman-Birk serine-proteinase inhibitor}

An example of biologically active proteins from lupin seeds is identification of the Bowman-Birk serine-proteinase inhibitor (Scarafoni et al. 2008), unlike some of the previous papers which excluded the presence of this remarkable protein molecule. The interest in proteins of this group is related to their proven effects in many pathological processes connected with inflammatory states including cancer, skeletal muscular atrophy, angiogenesis, rheumatoid arthritis, neurodegenerative and cardiovascular diseases.

\section{Glucose and insulin metabolism}

Also the presence of gamma-conglutin protein has been proven in lupins. It has been demonstrated on animal models that depending on the pharmacological dose gammaconglutin decreases the glucose level in blood (Magni et al. 2004). The most significant effect was observed at a concentration comparable with a half dose of metformin, a wellknown medicine to decrease the glucose level. Clinical studies are currently under way which should confirm this activity in humans. This is confirmed also by Garzón-de la Mora et al. (2015), who stated that Lupinus albus gamma-conglutin decreased glucose in healthy subjects and type 2 diabetes mellitus patients.

Schopen et al. (2015) studied short-term effects of lupin versus whey protein on glucose and insulin. The results conclude that lupin and whey protein can lower the increase of postprandial blood glucose levels to nearly the same extent, suggesting that lupin protein can be used as a valuable alternative to whey protein in reducing glycaemia. However, their insulin responses seem to be different.

Lupin protein extract was proven to be $\times 10$ more potent than the standard antidiabetic drug. The work of Agrawal et al. (2015) formed a basis for developing scalable and selective extraction process for bioactive gamma-conglutin with high yield and purity from lupin as a potential anti-diabetic oral health supplement.

\section{Anti-oxidation properties of lupin}

There is evidence that reactive oxygen including free radicals may lead to peroxidation of fats and oxidative stress which damages biological structures such as proteins, lipids and DNA. This results in body ageing and chronic diseases. The body has its own anti-oxidation system and resists free radicals using certain enzymes. The intake of antioxidants in food probably strengthens the protective anti-oxidation system of the body. Anti-oxidation properties are known in red wine, fruit, vegetables, and spices. The anti-oxidation capacity differs in individual species and varieties of lupin. Lupinus luteus, cultivar Pootalong, L. microcarpus and L. angustifolius, cultivar Kalya showed a stronger anti-oxidation activity than other species and cultivars (Wang and Clements 2008).

\section{Allergenic potential of lupin}

Allergic reactions have been observed after swallowing or inhaling lupin seed proteins. It is unclear what the lupin allergy occurrence is in the population, but it seems to be low. An interesting aspect is the cross reactivity of serum in patients sensitive to peanuts with lupin proteins and to proteins of other legumes. There are estimations that $30 \%$ (MoneretVautrin et al. 1999) or 4\% (Shaw et al. 2008) of individuals allergic to peanuts react also to lupin. The inclusion of lupin in the European list of allergenic food components, which is compulsory to be marked on food packages, indicates the need for further research in this field. 
The impact of thermal processing on legume allergens was studied by Verma et al. (2012). Thermal processing of legumes may reduce, eliminate or enhance the allergenic potential of a respective legume; in most of the cases, minimization of the allergenic potential upon thermal treatment has generally been reported.

The above-mentioned overview of using lupin in human nutrition has shown that lupin seeds and their products have mainly favourable dietetic effects on human body. Therefore, in some countries such as Australia they are very much appreciated and commonly offered in shops with other legume species.

\section{Using lupin in animal nutrition}

The mentioned nutraceutical properties verified in humans may take a secondary effect when including lupin seeds also in animal nutrition. Nevertheless, in animals the production efficiency or the impact on the biological value of food of animal origin is in the foreground.

\section{Using lupin in ruminant nutrition}

The possibilities of using lupin in the feed rations of milk cows and in the fattening of bullocks are summarized by Homolka et al. (2008). Inclusion of lupin seed meal in the feed rations for high-utility milk cows assumes crushing and flaking of seeds and their inclusion in the feed mixture for bullocks up to $30 \%(0.5 \mathrm{~kg} / 100 \mathrm{~kg}$ of live weight)), for milk cows up to $20 \%(0.4 \mathrm{~kg} / 100 \mathrm{~kg}$ live weight). Their advantage is that unlike soybeans, they need not be heat treated. Depending on the lupin variety, the degradability of lupin seed protein in rumen ranged from 71 to $79 \%$. The lipidic component of lupin has a favourable effect on the milky efficiency and milk fat and changes in the concentration of fatty acids with long strings in milk are positive from the viewpoint of human nutrition. Cattle can use even whole fodder plants as fresh fodder or ensilage. Lupin is an alternative to soy.

In sheep, Somchit-Assavacheep et al. (2013) monitored the effect of short-term nutritional supplementation with lupin grain (Lupinus luteus) on folliculogenesis, concentrations of hormones and glucose in plasma and follicular fluid. The numbers of follicles were increased in the lupin-fed group, glucose and insulin levels were also higher.

\section{Production efficiency of lupin in pigs}

Data on the effect of lupin on production efficiency in pigs are not homogenous. Reduced feed intake and growth of pigs fed a diet containing $150-430 \mathrm{~g} / \mathrm{kg}$ of $L$. albus seeds have been reported by Zettl et al. (1995). At a 30\% inclusion of white lupin in the feed mixture, they found a reduced feed intake, lower conversion of nutrients, and growth depression, while they did not observe a positive effect of dehulling and supplementation with amino acids. Conversely, in pigs fed a diet with L. angustifolius ( $410 \mathrm{~N}$ substances $\mathrm{g} / \mathrm{kg}$ of diet), compared to a barley- and soy-based diet, Gdala et al. (1996) did not observe growth depression. Positive results with yellow lupin of the Juno variety were also achieved by Flis et al. (1996). The nutritional value of diets with various contents of cultural lupins (L. angustifolius and L. albus) in fattened pigs were studied by Zralý et al. (2008; 2007) who proved that the animal protein or soybean could be completely replaced by lupin in the diet for fattened pigs provided that the limiting amino acids were balanced and the nutritional value was increased by fat supplementation and dehulling. No anti-nutritional effect was observed in the used representation of lupins in experimental diets.

Effects of feeding finisher pigs with chicory or lupin feed for one week or two weeks before slaughter with respect to levels of Bifidobacteria and Campylobacter were studied by Jensen et al. (2013). This study showed that even a short-term alternative feeding 
strategy with probiotics in the diet of pre-slaughter pigs elicited changes in the composition of the intestinal microbiota, where lupin increased the level of bifidobacteria in the caecum and reduced the Campylobacter spp. excretion level after one week.

\section{Production efficiency of lupin in poultry}

The inclusion of lupin seed in feed mixtures for broilers at a lower concentration (starter $15.5 \%$; grower $12.8 \%$; finisher $8.7 \%$ ) did not have a negative effect on efficiency indicators and selected carcass indicators. Lupin seed can replace soy extracted meal to ensure the need of both proteins and energy provided that the amino acids of methionine, lysine and threonine are balanced (Suchý et al. 2006a). The inclusion of lupin seed meal in feed mixtures for broilers did not have a negative effect on the chemical composition of breast and femoral musculature. Unlike the control group, in the experimental group of chickens taking lupin the proportion of n-3 and n-6 fatty acids in breast and femoral musculature narrowed, both in pullets and cockerels, which is a proof of an increased dietetic value of musculature.

On the other hand, replacement of soybean meal with yellow lupin seed meal in turkeys $(0 \%, 8 \%, 16 \%$, and $24 \%)$ did not have a positive effect on feed intake and body weight gain. A linear increase $(P \leq 0.001)$ in the concentrations of polyunsaturated fatty acids was noted in meat from turkeys fed with lupin-based diets; this did not change the n-6/n-3 PUFA ratio, but improved the values of the atherogenic and thrombogenic indices (Krawczyk et al. 2015).

Zdunczyk et al. (2014) study growth performance, gastrointestinal function and meat quality in growing-finishing turkeys fed diets with different levels $(6,12$ and 18\%) of yellow lupin (L. luteus) seeds meal (YLM). In the first phase of feeding YLM decrease feed intake and body weight gain linearly due to significant deterioration in the feed conversion ratio. An opposite trend was noted in the second phase of feeding. Body weight gain increased and feed conversion ratio improved significantly.

The effects of dietary replacement of soybean meal (SBM) with blue lupin meal (BLM) on the gastrointestinal tract (GIT) function, growth performance and meat quality in growing-finishing turkeys (13-18 weeks of age) were studied by Mikulski et al. (2014). In experimental diets SBM was replaced with BLM at 60,120 , and $180 \mathrm{~g} / \mathrm{kg}$. The increasing dietary inclusion levels of BLM caused a linear increase in feed intake and body weight gain (BWG), but they did not affect FCR and the mortality rates of turkeys. Feed intake and BWG were significantly higher in group $\mathrm{L}_{180}$ than in the control group. The highest BLM inclusion level had no adverse effect on enzyme activities in the GIT contents and short-chain fatty acid concentrations. No significant differences were found in carcass quality or the $\mathrm{pH}$ and colour intensity of breast meat.

\section{Acknowledgements}

This work was supported by IGA 214/2015/Faculty of Veterinary Hygiene and Ecology.

\section{References}

Agrawal S, Mane S, Majumdar D, Mazumdar A, Utikar R, Kale S 2015: Lupins: Potential oral health supplement for management of diabetes. In: Capraro J, Duranti M, Magni Ch, Scarafoni A (Eds): Proceedings of the XIV International Lupin Conference. Milan, Italy 21-26 June 2015, p. 83

Aniszewski T, Ciesiolka D, Gulewicz K 2001: Equilibrium between basic nitrogen compounds in lupin seeds with differentiated alkaloid content. Phytochemistry 57: 43-50

Archer BJ, Johnson SK, Devereux HM, Barter AL 2004: Effect of fat replacement by inulin or lupin-kernel fibre on sausage patty acceptability, post-meal perceptions of satiety and food intake in men. Brit J Nutr 91: 591-599

Arnoldi A, Boschin G, Zanoni C, Aiello G, Lammi C 2015: The health benefits of lupin in cardiovascular prevention: ten years of successful investigations. In: Capraro J, Duranti M, Magni Ch, Scarafoni A (Eds): Proceedings of the XIV International Lupin Conference. Milan, Italy 21-26 June 2015, pp. 77-80 
Bartkiene E, Schleining G, Rekstyte T, Krungleviciute V, Juodeikiene G, Vaiciulyte-Funk L, Maknickiene Z 2013: Influence of the addition of lupin sourdough with different lactobacilli on dough properties and bread quality. Int J Food Sci Tech 48: 2613-2620

Bouchenak M, Lamri-Senhadji M 2013: Nutritional quality of legumes, and their role in cardiometabolic risk prevention: A Review. J Med Food 16: 185-198

Chandra-Hioe MV, Arcot J 2015: Microbial biosynthesis to enhance vitamin B12 contents in Lupin flour. In: Capraro J, Duranti M, Magni Ch, Scarafoni A(Eds): Proceedings of the XIV International Lupin Conference. Milan, Italy 21-26 June 2015, pp. 84-86

Cowling WA, Huyghe C, Swiecicki W 1998: Lupin breeding. In: Gladstones JS, Atkins CA, Hamblin J (Eds): Lupins as crop plants: Biology, production and utilization. CAB International, Oxon, UK, pp 93-120

Dijkstra DS, Linnemann AR, Van Boekel TA 2003: Towards sustainable production of protein-rich foods: Appraisal of eight crops for Western Europe. PART II: Analysis of the technological aspects of the production chain. Crit Rev Food Sci Nutr 43: 481-506

Duranti M 2006: Grain legume proteins and nutraceutical properties. Fitoterapia 77: 67-82

Flis M, Sobotka W, Meller Z 1996: The use of dehulled or fat-supplemented yellow lupin seeds in feeding growing pigs. J Anim Feed Sci 5: 49-61

Fryirs C, Eisenhaur B, Duckworth S 2008: Luteins in lupins - an eye for health. In: Palta J A., Berger JD (Eds.): Proceedings of the $12^{\text {th }}$ International lupin conference. CSIRO Plant Industry, Wembley, Western Australia

Garzón-de la Mora P, Zarate-Guzman KJ, Munguia-Zuńiga LE, Garcia-Lopez P, Rodriguez- Macias R, Lopez JC, Garzón-Garcia C, Jimenez-Rodriguez LE 2015: Lupinus albus gamma conglutin decreases glucose in healthy subjects and type 2 diabetes mellitus patients. In: Capraro J, Duranti M, Magni Ch, Scarafoni A (Eds): Proceedings of the XIV International Lupin Conference. Milan, Italy 21-26 June 2015, p. 81

Gdala J, Jansman AJM, VanLeeuwen P, Husman J, Verstegen MWA 1996: Lupins (L. luteus, L. albus, L. angustifolius) as a protein source for young pigs. Anim Feed Sci Tech 62: 239-249

Gefrom A, Ott EM, Hoedtke S, Zeyner A 2013: Effect of ensiling moist field bean (Vicia faba), pea (Pisum sativum) and lupin (Lupinus spp.) grains on the contents of alkaloids, oligosaccharides and tannins. J Anim Physiol Anim Nutr 97: 1152-1160

Green BT, Lee ST, Panter KE, Brown DR 2012: Piperidine alkaloids: human and food animal teratogens. Food Chem Toxicol 50: 2049-2055

Hall RS, Johnson SK, Barter AL, Ball MJ 2005: Lupin kernel fibre-enriched foods beneficially modify serum lipids in men. Europ J Clin Nutr 59: 325-333

Hodgson J, Villarino CB, Jayasena V, Coorey R, Johnson S 2015: Can lupin consumption reduce risk factors associated with metabolic syndrome: current evidence and future studies. In: Capraro J, Duranti M, Magni Ch, Scarafoni A (Eds): Proceedings of the XIV International Lupin Conference. Milan, Italy 21-26 June 2015 , p. 76

Homolka P, Koukolová V, Kudrna V, Jančík F, Skřivanová V 2008: Use of lupin in cattle nutrition (in Czech). VÚŽV, Praha, 24 p.

Jensen AN, Hansen LL, Baggesen DL, Mølbak L 2013: Effects of feeding finisher pigs with chicory or lupin feed for one week or two weeks before slaughter with respect to levels of Bifidobacteria and Campylobacter. Animal 7: 66-74

Johnson SK, Gray DM 1993: Strong ingredients derived from lupin potential for a range of dietary fiber applications. Int Food Ingred 5: 18-23

Kapravelou G, Martínez R, Andrade AM, Sánchez C, Chaves CL, López-Jurado M, Aranda P, Cantarero S, Arrebola F, Fernández-Segura E, Galisteo M, Porres JM 2013: Health promoting effects of Lupin (Lupinus albus, var. multolupa) protein hydrolyzate and insoluble fiber in a diet-induced animal experimental model of hypercholesterolemia. Food Res Int 54: 1471-1481

Krawczyk M, Przywitowski M, Mikulski D 2015: Effect of yellow lupin (L. luteus) on the egg yolk fatty acid profile, the physicochemical and sensory properties of eggs, and laying hen performance. Poult Sci 94: 1360-1367

Lammi C, Zanoni C, Scigliuolo GM, D’Amato A, Arnoldi A 2014: Lupin peptides lower low-density lipoprotein (LDL) cholesterol through an up-regulation of the LDL receptor/sterol regulatory element binding protein 2 (SREBP2) pathway at HepG2 cell line. J Agric Food Chem 62: 7151-7159

Lammi C, Zanoni C, Scigliuolo GM, D’Amato A, Arnoldi A 2015: Molecular investigation of the mechanism of action through which lupin peptides induce hypocholesterolemic effects on HepG2 cells. In: Capraro J, Duranti M, Magni Ch, Scarafoni A (Eds): Proceedings of the XIV International Lupin Conference. Milan, Italy 21-26 June 2015, pp. 91-94

Lee YP, Mori TA, Sipsas S, Barden A, Puddey IB, Burke V, Hall RS, Hodgson JM 2006: Lupin-enriched bread increases satiety and reduces energy intake acutely. Am J Clin Nutr 84: 975-980

Magni C, Sessa F, Accardo E, Banini M, Morazzoni P, Scarafoni A, Duranti M 2004: Conglutin gamma, a lupin seed protein, binds insulin in vitro and reduces plasma glucose levels of hyperglycemic rats: J Nutr Biochem 15: 646-650

Martins JM, Riottot M, de Abreu MC, Virgas-Crespo AM, Lanca MJ, Almeida JA, Freire JB, Bento OB 2005: Cholesterol-lowering effects of dietary blue lupin (Lupinus angustifolius L.) in intact and ileorectal anastomosed pigs. J Lipid Res 46: 1539-1547 
Moneret-Vautrin DA, Guerin L, Kanny G, Flabbee J, Frémont S, Morisset M 1999: Cross-allergenicity of peanut and lupin: The risk of lupin allergy in patients allergic to peanuts. J Allergy Clin Imun 104: 883-888

Msika P, Piccirilli A, Paul F 2006: Peptide extract of lupin and pharmaceutical or cosmetic or nutritional composition comprising the same. US Patent 7029713

Petterson DS, Sipsas S, Macintosh JB 1997: The chemical composition and nutritive value of Australian pulses. Greins Research and Development Corporation, Canberra, Australia, 68 p.

Pilvi TK, Jauhiainen T, Cheby ZJ, Mervaala EM, Vapaatalo H, Korpela R 2006: Lupin protein attenuates the development of hypertension and normalises the vascular function of NaCl-loaded Goto-Kakizaki rats. J Physiol Pharmacol 57: 167-176

Písaříková B, Zralý Z 2009: Nutritional value of lupin in the diets for pigs (a review). Acta Vet Brno 78: 399-409

Scarafoni A, Consonni A, Galbusera V, Negri A, Tedeschi G, Rasmussen P 2008: Identification and characterization of a Bowman-Birk inhibitor active towards trypsin but not chymotrypsin in Lupinus albus seeds. Phytochemistry 69: 1820-1825

Schopen K, Ewald AC, Frings-Meuthen P 2015: Short term effects of lupin versus whey protein on glucose and insulin responses to a standardized meal. In: Capraro J, Duranti M, Magni Ch, Scarafoni A (Eds): Proceedings of the XIV International Lupin Conference. Milan, Italy 21-26 June 2015, p. 82

Shaw J, Robert G, Grimshaw K, White S, Hourihane J 2008: Lupin allergy in peanut-allergic children and teenagers. Allergy 63: 370-373

Sirtori CR, Lovati MR, Manzoni C, Castiglioni S, Duranti M, Magni C, Morandi S, D’Agostina A, Arnoldi A 2004: Proteins of white lupin seed, a naturally isoflavone-poor legume, reduce cholesterolemia in rats and increase LDL receptor activity in HepG2 cells. J Nutr 134: 18-23

Somchit-Assavacheep A, Campbell BK, Khalid M, Kendall NR, Scaramuzzi RJ 2013: The effect of short-term nutritional supplementation of ewes with lupin grain (Lupinus luteus) on folliculogenesis, the concentrations of hormones and glucose in plasma and follicular fluid and the follicular levels of P450 aromatase and IRS1, -2 and -4. Reproduction 145: 319-333

Stanek M, Bogusz J, Sobotka W, Bieniaszewski 2006: Nutritive value of new varieties of yellow lupin (Lupinus luteus) and narrow-leaved lupin (Lupinus angustifolius). Ann Anim Sci 2/1: 206-210

Stanek M, Rotkiewicz T, Sobotka W, Bogusz J, Otrocka-Domagala I, Rotkiewicz A 2015: The effect of alkaloids present in blue lupin (Lupinus angustifolius) seeds on the growth rate, selected biochemical blood indicators and histopathological changes in the liver of rats. Acta Vet Brno 84: 55-62

Straková E, Suchý P, Večerek V, Šerman V, Mas N, Juzl M 2006: Nutritional composition of seeds of the genus Lupinus. Acta Vet Brno 75: 489-493

Streppel MT, Arends LR, Van't Veer P, Grobbee DE, Geleijnse JM 2005: Dietary fiber and blood pressure: a meta-analysis of randomized placebo-controlled trials. Arch Intern Med 165: 150-156

Suchý P, Straková E, Herzig I 2006a: Nutritive and dietetic value of domestic protein feeds as an alternative to soya and soya products. Part I - Lupin (in Czech). Research Institute for Animal Production PragueUhř́něves, Scientific Committee for Animal Nutrition, 54 p. Suchý P, Straková E, Večerek V, Šerman V, Mas N 2006b: Testing of two varieties of lupin seeds as substitutes for soya extracted meal in vegetable diets designed for young broilers Acta Vet Brno 75: 495-500

Verma AK, Sandeep K, Das M, Premendra D 2012: Impact of thermal processing on legume allergens. Plant Food Hum Nutr 67: 430-441

Viveros A, Centeno C, Arija I, Brenes A 2007: Cholesterol-lowering effects of dietary lupin (Lupinus albus var. Multolupa) in chicken diets. Poultry Sci 86: 2631-2638

Wang S, Clements J 2008: Antioxidant activities of lupin seeds. In: Palta JA, Berger JD (Eds): Proceedings of the $12^{\text {th }}$ International Lupin Conference. CSIRO Plant Industry, Wembley, Western Australia, pp. 546-549

Whelton SP, Hyre AD, Pedersen B, Yi Y, Whelton PK, He J 2005: Effect of dietary fiber intake on blood pressure: A meta-analysis of randomized, controlled clinical trials. J Hypertens 23: 475-481

Yanez E, Ivanovic D, Owen DF, Ballester D 1983: Chemical and nutritional-evaluation of sweet lupins. Ann Nutr Metab 27: 513-520

Mikulski D, Zduńczyk Z, Juśkiewicz J, Rogiewicz A, Jankowski J 2014: The effect of different blue lupin (L. angustifolius) inclusion levels on gastrointestinal function, growth performance and meat quality in growing-finishing turkeys. Anim Feed Sci Technol 198: 347-352

Zduńczyk Z, Jankowski J, Rutkowski A, Sosnowska E, Drażbo A, Zduńczyk P, Juśkiewicz J 2014: The composition and enzymatic activity of gut microbiota in laying hens fed supplemented with blue lupine seeds. Anim Feed Sci Technol p. 191: 57-66

Zeman L, Šimeček K, Krása A 1995: Tables of nutritional values of feeds. VÚVZ, Pohořelice, 465 p.

Zettl A, Lettner F, Wetscherek W 1995: Use of white sweet lupin seed (Lupinus. albus var. Amiga) in a diet for pig fattening. Bodenkultur 46: 165-173

Zielińska-Dawidziak M 2015: Lupin ferritin application for enrichment food in iron. In: Capraro J, Duranti M, Magni Ch, Scarafoni A (Eds): Proceedings of the XIV International Lupin Conference. Milan, Italy 21-26 June 2015, pp. 87-90

Zralý Z, Písaříková B, Trčková M, Doležal M, Thiemel J, Simeonovová J, Juzl M 2008: Replacement of soya in pig diets with white lupin cv. Butan. Czech J Anim Sci 53: 418-430 
Zralý Z, Písaříková B, Trčková M, Herzig I, Juzl M, Simeonovová J 2007: The effect of white lupin on the performance, health, carcass characteristics and meat quality of market pigs. Vet Med Czech 52: 29-41 